\title{
Determination of Advanced Glycation End Products in Serum by Fluorescence Spectroscopy and Competitive $\operatorname{ELISA}^{1}$ )
}

\author{
Gerald Münch, Regina Keis, Andrea Weßels, Peter Riederer, Udo Bahner, August Heidland, Toshimitsu Niwa, \\ Horst-Dieter Lemke and Reinhard Schinzel
}

Physiologische Chemie I, Biozentrum, Am Hubland, Würzburg, Germany

Summary: Recent studies suggest that advanced glycation endproducts play an important role in cardiovascular complications of ageing, diabetes and end-stage renal failure. Since highly elevated levels of advanced glycation endproducts are present in serum of patients on maintenance haemodialysis, an accurate and rapid assay for their determination would be useful. This would be particularly valuable for monitoring the removal of advanced glycation endproducts by novel dialysis membranes, as well as the effect of new drugs for the inhibition of their formation.

Measurement of advanced glycation endproducts in serum was performed by two competitive ELISAs, using a monoclonal antibody directed against imidazolone, an advanced glycation endproduct formed by the reaction of arginine with 3-deoxyglucosone, and a polyclonal antibody directed against keyhole limpet haemocyanin-advanced glycation endproduct, as well as by quantitative fluorescence spectroscopy.

Each of the assays showed significant differences between the controls and the maintenance haemodialysis patients. Advanced glycation endproduct levels determined by each of the ELISAs correlated with total and protein-bound fluorescence, but not with each other, suggesting a variable distribution of advanced glycation endproducts on serum proteins among the maintenance haemodialysis patients.

\section{Introduction}

Advanced glycation endproducts are generated by the non-enzymatic reaction of a sugar ketone or aldehyde group with the free amino group of proteins or amino acids. In the first step, a labile Schiff base is formed, which subsequently rearranges into the stable Amadoriproduct. Finally, advanced glycation endproducts are formed as a mixture of protein-bound nitrogen and oxygen-containing heterocyclic compounds through a complex cascade of dehydration, condensation, fragmentation, oxidation and cyclization reactions $(1,2)$. A variety of chemical advanced glycation endproduct structures have been elucidated, some of which are non-fluorescent like $\mathrm{N}^{\varepsilon}$-(carboxymethyl)lysine, pyralline or imidazolone, or fluorescent like pentosidine or the crosslinks $(3,4)$.

A mild rise of advanced glycation levels is associated with normal ageing in long-lived tissue proteins, e. g. in collagen, where it has been shown that the glycoxidation products, e.g. $\mathrm{N}^{\mathrm{E}}$-(carboxymethyl)lysine and pentosidine, as well as glycation-related collagen-linked fluorescence increase with age (5).

\footnotetext{
1) Funding organisations:

Claussen-Stiftung

Hirnliga e. V.

Jubiläumsstiftung der Universität Würzburg
}

A more striking rise of advanced glycation endproducts is observed in diabetic patients as a result of sustained hyperglycaemia. In uraemia, the rise of advanced glycation endproducts is even more marked than in diabetics and is associated with a variety of tissue disorders including vascular damage, dyslipidaemia, and $\beta_{2}$-microglobulin amyloidosis. Whereas in diabetes, higher advanced glycation endproduct levels are caused by an elevated level of plasma glucose, the major mechanism for increased advanced glycation endproduct levels in endstage renal failure might be the impaired renal excretion and the insufficient clearance by dialysis membranes $(6-9)$.

Advanced glycation endproduct-mediated crosslinks generated in proteins contribute to the age-related decline in the function of cells and tissues in the normal ageing process, in Alzheimer's disease, in diabetes and maintenance haemodialysis (10-12). Recent progress in the understanding of this process has affirmed the hypothesis that advanced glycation endproducts play an important role in the evolution of accelerated vascular complications in diabetes, end-stage renal failure and renal replacement therapy with maintenance haemodialysis. Advanced glycation endproducts have been identified in a variety of lipoprotein and lipid constituents of the vascular wall, leading to micro- and macroangiopathy, the so called "late diabetic complications". In detail, atherosclerosis, cataract and diabetic retinopathy, ne- 
phropathy and polyneuropathy may be caused by advanced glycation endproducts $(13-15)$. Thus it is believed that the use of dialysis procedures and membranes that lower the level of advanced glycation endproducts may be a promising approach to lowering the risk of cardiovascular complications for patients.

So far, the advanced glycation endproduct level in serum or plasma has been measured by HPLC with fluorescence detection of a single substance such as pentosidine or, in most studies, by competitive ELISA with poly- or monoclonal antibodies raised against synthetic advanced glycation endproducts. In this study we compare advanced glycation endproduct levels determined by total and protein-bound fluorescence with those determined by competitive ELISAs using two different antibodies.

\section{Methods}

\section{Serum samples}

Serum was obtained from 19 control subjects (age: $69.7 \pm 7.8$ years) and 153 patients on long term maintenance haemodialysis therapy (age: $62.7 \pm 13.1$ years, $5.1 \pm 4.8$ years on dialysis). The intervals between dialysis sessions were $48-72$ hours. Serum was stored frozen at $-20^{\circ} \mathrm{C}$.

\section{Quantitative fluorescence spectroscopy}

Serum was diluted 500 fold with phosphate-buffered saline. Due to the viscosity of the serum, $20 \mu$ l (sensitivity limit) were used and diluted into $10 \mathrm{ml}$. After filtration through Millex-GV filters $(0.22 \mu \mathrm{m}$ Millipore), fluorescence spectra (corrected for background) were recorded in triplicate on a Fluoromax spectrometer (Spex instruments) at room temperature. Emission and excitation slid widths were set to one $\mathrm{nm}$. To compare different sera, the excitation wavelength was set to $370 \mathrm{~nm}$, and the signal intensity was measured at the emission maximum of $445 \mathrm{~nm}$ and expressed in arbitrary units (2). The inter-assay coefficient of variation was $8.9 \%$ (triplicates on the same day, $\mathrm{n}=35$ ). Day to day variation (5 days) was $10.5 \%(n=35)$.

\section{Competitive ELISA}

Polyclonal keyhole limpet haemocyanin-advanced glycation endproduct antibody

The polyclonal rabbit antibody was raised against advanced glycation endproduct-modified keyhole limpet haemocyanin, which had been prepared by incubating the protein with $1 \mathrm{~mol} / 1$ glucose for 3 months at $50^{\circ} \mathrm{C}$. The ELISA was performed in triplicate in a modification of the assay employed by Papanastasiou et al. (16). Briefly, 96-well microtitre plates were coated overnight with artificial bovine serum albumin-advanced glycation endproduct $(3 \mathrm{mg} / 1$ in $0.1 \mathrm{~mol} / 1$ sodium carbonate buffer, $\mathrm{pH} \mathrm{9.5).} \mathrm{Wells} \mathrm{were} \mathrm{blocked}$ for one hour with phosphate-buffered saline containing $60 \mathrm{~g} / \mathrm{l}$ bovine serum albumin, $10 \mathrm{ml} / 1$ foetal calf serum and $0.5 \mathrm{~g} / 1$ Tween 20. Serum samples, diluted $1: 4$ in assay buffer (phosphate-buffered saline $+0.5 \mathrm{~mol} / 1 \mathrm{KCl}, 0.5 \mathrm{~g} / \mathrm{l}$ Tween 20 and $60 \mathrm{~g} / \mathrm{l}$ bovine serum albumin), were added to antiserum $(1: 400)$. After incubation for two hours and three washing steps, alkaline phosphatelinked anti rabbit IgG $(1: 2000)$ in wash buffer (phosphate-buffered saline with $0.5 \mathrm{~g} / 1$ Tween 20 ) was added, incubated for one hour and washed again. Colour was developed with $p$-nitrophenylphosphate diluted in glycine buffer (pH 10.4); absorbance at 405 $\mathrm{nm}$ was read in a microplate reader. The inter-assay coefficient of variation was $6.60 \%$ (triplicates on the same day, $n=172$ ). Day to day variation ( 3 days) was $8.75 \%(n=19)$.

\section{Monoclonal imidazolone antibody}

The anti-imidazolone antibody was raised by immunizing mice with advanced glycation endproduct-modified keyhole limpet haemocyanin produced by incubating the protein with glucose. One of the two resulting positive clones specifically recognized imidazolone (3). The 96-well microtitre plate was coated overnight with synthetic bovine serum albumin-advanced glycation endproduct

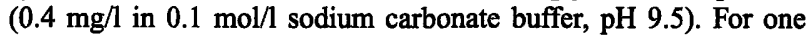
hour the wells were blocked with blocking buffer (phosphate-buffered saline $+60 \mathrm{~g} / 1$ bovine serum albumin $+0.5 \mathrm{~g} / 1$ Tween 20). After one washing step, serum samples, diluted $1: 4$ in wash buffer (phosphate-buffered saline $+0.5 \mathrm{~g} / 1$ Tween 20), were added to the antiserum (dilution: $1: 2000$ ) and incubated for two hours. They were washed six times, then peroxidase-linked anti mouse IgG $(1: 10000)$ in wash buffer was added. After incubation for one hour and six washing steps, colour was developed with 2,2 '-azinobis(3-ethylbenzthiazoline-6-sulphonic acid) and $\mathrm{H}_{2} \mathrm{O}_{2}$ in substrate buffer $\left(\mathrm{NaCH}_{3} \mathrm{COO}+\mathrm{NaH}_{2} \mathrm{PO}_{4}, \mathrm{pH} 4.2\right)$. The absorbance was also read in a microplate reader at $405 \mathrm{~nm}$. The inter-assay coefficient of variation was $5.54 \%$ (triplicates on the same day, $n=79$ ). Day to day variation ( 3 days) was $4.35 \%(n=10)$. All steps in both ELISAs were performed at room temperature with the exception of the colour reaction at $37^{\circ} \mathrm{C}$.

\section{Production of synthetic advanced glycation} endproducts

Bovine serum albumin or chicken egg albumin $(50 \mathrm{~g} / \mathrm{l})$ were incubated in $0.1 \mathrm{~mol} / 1$ phosphate buffer $(\mathrm{pH} 7.9)$ at $50^{\circ} \mathrm{C}$ with $1 \mathrm{~mol} / 1$ glucose for 2 months in loosely capped bottles. Water was added twice a week to compensate for solvent evaporation. Synthetic advanced glycation endproducts were dialysed extensively against phosphate buffer to remove non-protein bound advanced glycation endproducts and residual sugars.

\section{Protein precipitation with trichloroacetic acid}

Serum proteins of 21 patients were precipitated with trichloroacetic acid $100 \mathrm{~g} / 1$ for 20 minutes on ice (17). After centrifugation for 15 minutes at $5000 \mathrm{~g}$ and 3 washing steps with trichloroacetic acid $100 \mathrm{~g} / \mathrm{l}$, the pellets were redissolved in $0.1 \mathrm{~mol} / \mathrm{l}$ Tris buffer $(\mathrm{pH}$ 11.3), then used for SDS polyacrylamide gel electrophoresis and fluorescence spectroscopy.

\section{Gel filtration chromatography}

Molecular masses of serum advanced glycation endproducts (50 $\mu 1)$ were determined by gel filtration chromatography on a Tosohaas TSKgel G $3000 \mathrm{SW}$ column in phosphate-buffered saline. Flow rate was set to $2 \mathrm{ml} / \mathrm{min}$. Absorption was measured with a Biorad 1706 UV/VIS photometer at $280 \mathrm{~nm}$ and with a MerckHitachi F-1080 fluorospectrometer at a excitation wavelength of $370 \mathrm{~nm}$ and an emission wavelength of $440 \mathrm{~nm}$. Bovine serum albumin $\left(M_{\mathrm{r}} 67000\right)$, chicken egg albumin $\left(M_{\mathrm{r}} 46000\right)$ and cytochrome c $\left(M_{\mathrm{r}} 12000\right)$ were used as molecular mass standards for calibration of the column.

\section{Statistics}

Statistical evaluation was performed with the Macintosh based Abacus Statview program. Correlations were calculated using Fischer's $\mathbf{r}$ to $\mathrm{z}$ with pairwise deletions. Statistical significance among groups was calculated by Student's $t$ test for unpaired samples.

\section{Results}

\section{Validation of the method}

Advanced glycation endproduct levels determined by competitive ELISA have been shown to be robust 
towards different assay conditions such as sample preparation, delipidation or (compared with internal standards) different antibody batches $(8,9,16)$.

In contrast, the characteristic advanced glycation endproduct fluorescence is more likely to be sensitive to unspecific interferences, e.g. by low molecular mass fluorescent compounds with similar emission spectra such as NADH, pteridine derivatives or haemoglobin. In particular, NADH and pteridine derivatives (folic acid, biopterin, neopterin) have fluorescence spectra similar to advanced glycation endproducts.

\section{Reduced pyridine nucleotide}

NADH has an emission maximum of $440 \mathrm{~nm}$, but its concentration in serum is negligible, except when massive cell lysis with release from intracellular compartments occurs. However, there is no indication for an increased NADH level in the plasma of dialysis patients.

\section{Pteridine derivatives}

This second class of low molecular mass fluorescent compounds in serum consists of substances containing the pteridine ring such as folic acid, biopterin and neopterin. While the fluorescence of folic acid is negligible at physiological concentrations, biopterin and neopterin may contribute up to $1 \%$ to the total fluorescence at maximum physiological levels (tab. 1).

\section{Haemoglobin}

Haemoglobin might also interfere with advanced glycation endproduct fluorescence emission. When haemoglobin was added in increasing concentrations up to 0.1 $\mathrm{g} / 1$ to serum samples, the emission maximum gradually shifted to $455 \mathrm{~nm}$ and the signal at the reference emission wavelength at $445 \mathrm{~nm}$ was reduced up to $8.5 \%$, presumably by quenching. At higher concentrations of haemoglobin, the maximum emission peak shifted to
$460 \mathrm{~nm}$; clearly, therefore, haemolytic sera should not be measured. However, the haemoglobin concentration in all tested serum samples did not exceed the physiological reference interval of $0.1 \mathrm{~g} / 1$ (18).

The serum level of the compounds mentioned above can also be estimated by observing $\mathrm{pH}$-dependent changes in fluorescence. Whereas the fluorescence of advanced glycation endproducts is insensitive to $\mathrm{pH}$ changes between $\mathrm{pH} 6$ and 10, fluorescence emission of pteridine derivatives as well as of NADH decreases at lower $\mathrm{pH}$ values (tab. 1). Since fluorescence of the serum did not change when the $\mathrm{pH}$ was lowered (tab. 1), it is likely that these compounds do not significantly contribute to the fluorescence of the serum.

\section{Measurement of serum advanced glycation endproduct level by competitive ELISAs}

The competitive ELISA measures the ability of the serum to compete with the immobilised advanced glycation endproduct on the microtitre plate surface for binding to the first advanced glycation endproduct antibody. The serum samples were used in dilutions ranging from $1: 16$ to $1: 2$. The sample without added serum served as internal standard on each plate and was defined as $B_{0}$. The degree of displacement of each dilution was expressed as the $B / B_{0}$ ratio. A serum dilution of $1: 4$ yielded the best signal/noise ratio with a low standard deviation, hence this dilution was used routinely and should be regarded as the sensitivity limit of this assay. To simplify data calculation, we have defined a $50 \%$ competition (at a fixed serum dilution of $1: 4$ ) as 1 unit of advanced glycation endproducts.

\section{Polyclonal keyhole limpet haemocyanin advanced glycation endproduct antibody}

The polyclonal antibody was raised against an artificial advanced glycation endproduct which had been produced by the incubation of keyhole limpet haemocyanin

Tab. 1 Fluorescence of possibly interfering compounds in the serum

\begin{tabular}{|c|c|c|c|c|}
\hline & \multirow[t]{2}{*}{$\begin{array}{l}\text { Concentration } \\
\text { in serum }\end{array}$} & \multirow[t]{2}{*}{$\begin{array}{l}\text { Concentration } \\
\text { measured }\end{array}$} & \multicolumn{2}{|c|}{$\begin{array}{l}\text { Fluorescence at } \\
440 \mathrm{~nm} \text { in } 10^{3} \mathrm{arb} \text {. units }\end{array}$} \\
\hline & & & $\mathrm{pH} 5.0^{\mathrm{a}}$ & $\mathrm{pH} 7.6^{\mathrm{b}}$ \\
\hline Biopterin & $<35 \mathrm{nmol} / 1$ & $100 \mathrm{nmol} / 1$ & 125 & 280 \\
\hline Folic acid & $5-20 \mathrm{nmol} / /^{\mathrm{c}}$ & $100 \mathrm{nmol} / \mathrm{l}$ & 0.8 & 1.6 \\
\hline $\mathrm{NADH}$ & & $100 \mathrm{nmol} / 1$ & 0.45 & 0.99 \\
\hline Haemoglobin & $0.1 \mathrm{~g} / \mathrm{l}^{\mathrm{e}}$ & $0.1 \mathrm{~g} / 1$ & 39 & 43 \\
\hline Advanced glycation endproduct-bovine serum albumin ${ }^{c}$ & & $0.1 \mathrm{~g} / 1$ & 400 & 370 \\
\hline Serum & & & 460000 & 510000 \\
\hline
\end{tabular}

a in $50 \mathrm{mmol} / \mathrm{l}$ citrate buffer

b in phosphate-buffered saline

c artificial advanced glycation endproduct-bovine serum albumin prepared by the incubation of bovine serum albumin $60 \mathrm{~g} / 1$ with glucose $0.5 \mathrm{~mol} / 1$ at $50^{\circ} \mathrm{C}$ for 2 months

\footnotetext{
d values for undiluted serum calculated from the values measured at a dilution of $1: 500$

e from 1.c. (20)
} 


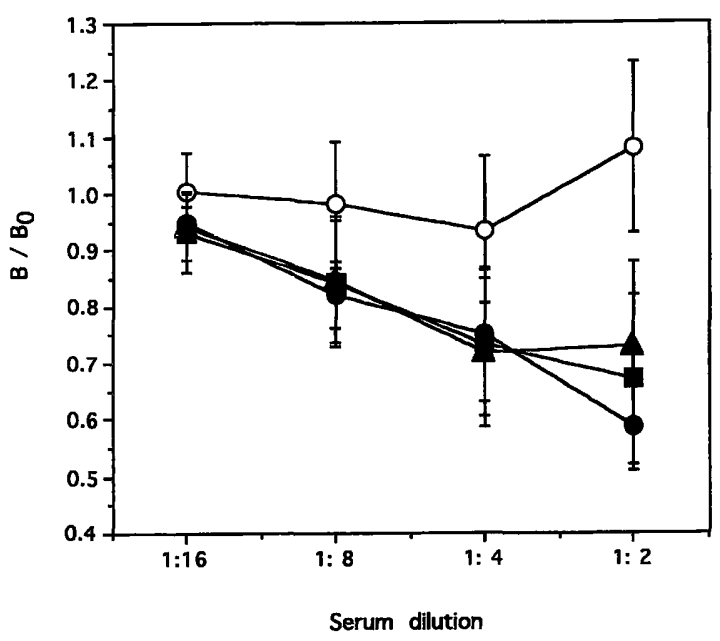

Fig. 1 Displacement curves of the competitive ELISA using the polyclonal keyhole limpet haemocyanin-advanced glycation endproduct antibody. A typical displacement curve of synthetic advanced glycation endproducts by serum samples of one control (open circles) and three haemodialysis patients (triangles, filled squares, filled circles) is shown in a dilution range from $1: 2$ to $1: 16$. Assays were done in triplicate, $\mathrm{B} / \mathrm{B}_{0}$ values are shown as mean $\pm \mathrm{SD}$.

with glucose. It has been shown that $\mathrm{N}^{\varepsilon}$-(carboxymethyl)lysine is the major antigenic epitope detected by this common types of advanced glycation endproduct antibody $(19,20)$. Typical displacement curves for the polyclonal antibody (one control and 3 maintenance haemodialysis patients) are shown in figure 1 . When this antibody was used, the serum advanced glycation endproduct level of the haemodialysis patients $(0.32 \pm 0.16$ units) were found to be significantly higher than that of the control subjects $(0 \pm 0.26, p<0.0001)$, but with a significant overlap between the patient and control group (fig. 2, tab. 2). No difference could be detected between diabetic and non-diabetic dialysis patients (tab. 2). The calculated advanced glycation endproduct level of around zero for the control subjects does not imply that their serum is devoid of advanced glycation endproducts. This result is probably due to the set-up of the assay. Bovine serum albumin, which is assumed to bind the same number of advanced glycation endproduct epitopes as human serum albumin in the tested sera, is used as a blocking reagent in the ELISA; it provides an excess of binding sites for the polyclonal antibody on the microtitre plate surface which is then unavailable for competition. The use of Tween 20 as an alternative blocking reagent led to a slightly lower background, but much higher standard errors among the triplicate measurements.

\section{Monoclonal imidazolone antibody}

The monoclonal antibody was raised against imidazolone, a reaction product of arginine and 3-deoxyglucosone, which was shown to be accumulated in the amyloid tissues of uraemic patients (3). The displacement curves were very similar to those of the polyclonal antibody with a maximal displacement of 53\% (1.06 units) for the patient serum with the highest imidazolone level. When this antibody was used, the advanced glycation endproduct level of the haemodialysis patients $(0.30$ \pm 0.25 units) was also found to be significantly higher than that of the control subjects $(0.13 \pm 0.12, \mathrm{p}<0.05)$, with a significant overlap between the patient and control group (fig. 3, tab. 2). No significant difference could be detected between diabetic and non-diabetic haemodialysis patients (tab. 2).

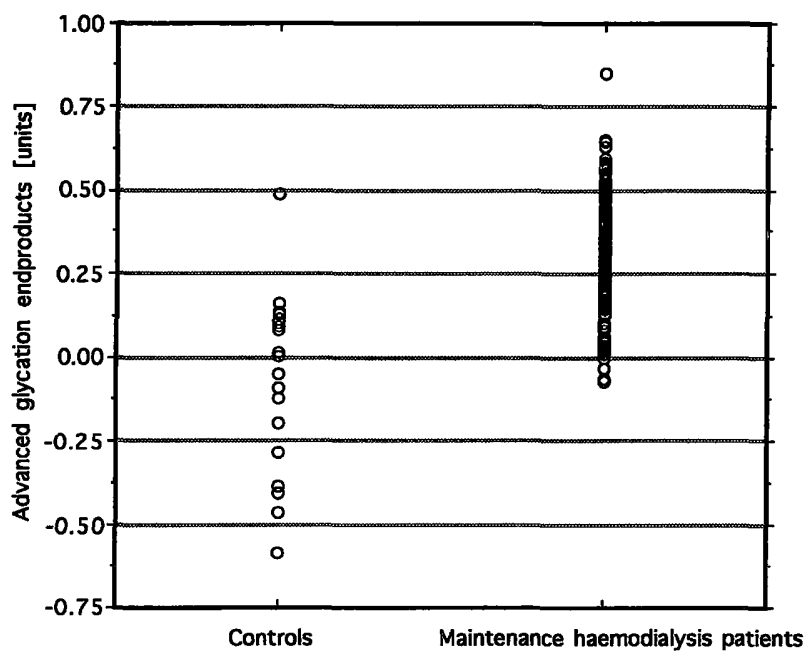

Fig. 2 Comparison of advanced glycation endproduct levels in serum of haemodialysis patients and controls measured by competitive ELISA (polyclonal keyhole limpet haemocyanin-advanced glycation endproduct antibody). The advanced glycation endproduct level in serum (at a $1: 4$ dilution) is $0 \pm 0.26$ units in the control group (left column) and $0.32 \pm 0.16$ units in the maintenance haemodialysis patients group (right column); these values are significantly different $(\mathrm{p}<0.0001)$.

Tab. 2 Advanced glycation endproduct levels in diabetic and non-diabetic maintenance dialysis patients determined by three independent assays

\begin{tabular}{|c|c|c|c|}
\hline & $\begin{array}{l}\text { ELISA } \\
\text { (polyclonal advanced } \\
\text { glycation endproduct antibody) } \\
\text { [units] }\end{array}$ & $\begin{array}{l}\text { ELISA } \\
\text { (monoclonal imidazolone } \\
\text { antibody) } \\
\text { [units] }\end{array}$ & $\begin{array}{l}\text { Total fluorescence } \\
{\left[10^{3} \text { arb. units }\right]}\end{array}$ \\
\hline Control & $0+0.26(n=20)$ & $0.13+0.12(\mathrm{n}=12)$ & $30.4+6.1(n=21)$ \\
\hline Non-diabetic haemodialysis patients & $0.33+0.17(\mathbf{n}=120)$ & $0.33+0.28(n=43)$ & $113.4+27.1(\mathrm{n}=116)$ \\
\hline Diabetic haemodialysis patients & $0.30+0.15(\mathrm{n}=37)$ & $0.23+0.17(n=14)$ & $107.9+29.1(n=37)$ \\
\hline
\end{tabular}




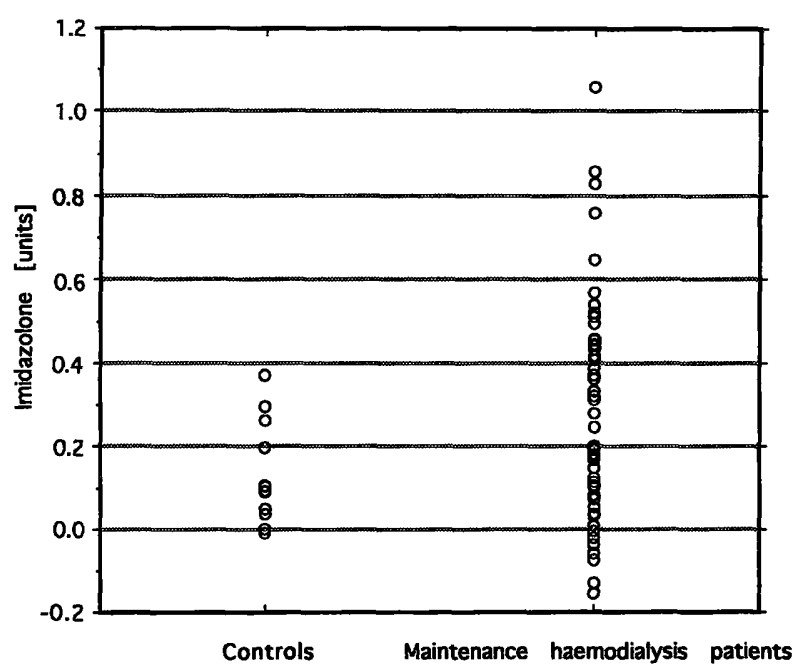

Fig. 3 Comparison of advanced glycation endproduct levels in serum of haemodialysis patients and controls measured by competitive ELISA (monoclonal imidazolone antibody). The advanced glycation endproduct level in serum (at a $1: 4$ dilution) is 0.13 \pm 0.12 units in the control group (left column) and $(0.30 \pm 0.25$ units) in the haemodialysis patients group (right column); these values are significantly different $(p<0.05)$.

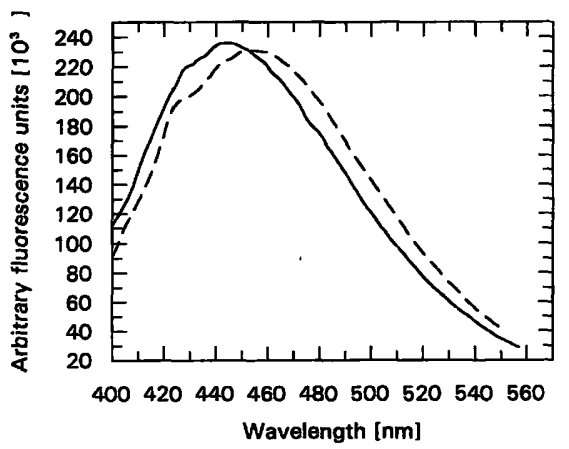

Fig. 4 Fluorescence spectra of synthetic advanced glycation endproducts and advanced glycation endproducts in serum. A fluorescence emission scan between 400 and $540 \mathrm{~nm}$ (excitation at 370 $\mathrm{nm}$ ) was recorded with synthetic advanced glycation endproducts and serum. All tested synthetic advanced glycation endproducts (bovine serum albumin-advanced glycation endproduct is shown as a representative sample) show a fluorescence spectrum nearly identical to that of serum.

\section{Measurement of serum advanced glycation endproduct level by fluorescence spectroscopy}

Protein-bound fluorescent substances in tissue and blood are generated by a complex reaction cascade involving glycation and oxidation ("glycoxidation") accompanied by the formation of oxygen free radicals with subsequent lipid peroxidation and protein oxidation $(21-23)$. Although oxidised amino acids on proteins also contribute to serum fluorescence (24), a similar fluorescence spectrum of synthetic advanced glycation endproducts and of those of serum supports the assumption that advanced glycation endproducts are the main fluorescent species in the serum of haemodialysis patients (fig. 4).

The advanced glycation endproduct level was determined by quantitative fluorescence spectroscopy with the same serum samples as used for the ELISAs. As in the immunological assays, significantly elevated advanced glycation endproduct levels were detectable in maintenance haemodialysis patients compared with the control subjects $\left(111.9 \times 10^{3} \pm 27.6 \times 10^{3}\right.$ vs. $30.7 \times 10^{3} \pm 6.2 \times 10^{3}$ arbitrary fluorescence units, $p<0.0001$ ). Interestingly, there was only a minimal overlap between the control and patient group (fig. 5).

\section{Determination of the molecular mass of fluorescent advanced glycation endproducts}

We used two methods, protein precipitation by trichloroacetic acid and gel filtration chromatography, to determine which structures the fluorescence is bound to. Firstly, serum of 21 patients was precipitated with trichloroacetic acid. Trichloroacetic acid precipitates proteins and DNA, but leaves low molecular mass compounds (e. g. low molecular mass peptides, oligonucleotides and organic compounds) in the supernatant (17). Analysis of the redissolved protein pellet by SDS polyacrylamide gel electrophoresis showed that predominantly albumin is recovered (data not shown). Fluorescence in the redissolved pellet decreased from 29.6 $\times 10^{3} \pm 4.8 \times 10^{3}$ to $20.7 \times 10^{3} \pm 11.2 \times 10^{3}$ arbitrary units in the control $(\mathrm{n}=12)$, and from $114.4 \times 10^{3}$ $\pm 25.7 \times 10^{3}$ to $61.9 \times 10^{3}$ arbitrary units in the haemodialysis patient group $(n=9)$. The fluorescence after the trichloroacetic acid precipitation step correlated well with the total fluorescence $(r=0.81, p<0.0001)$, indicating that the albumin advanced glycation endproduct content reflects closely the total fluorescence in serum.

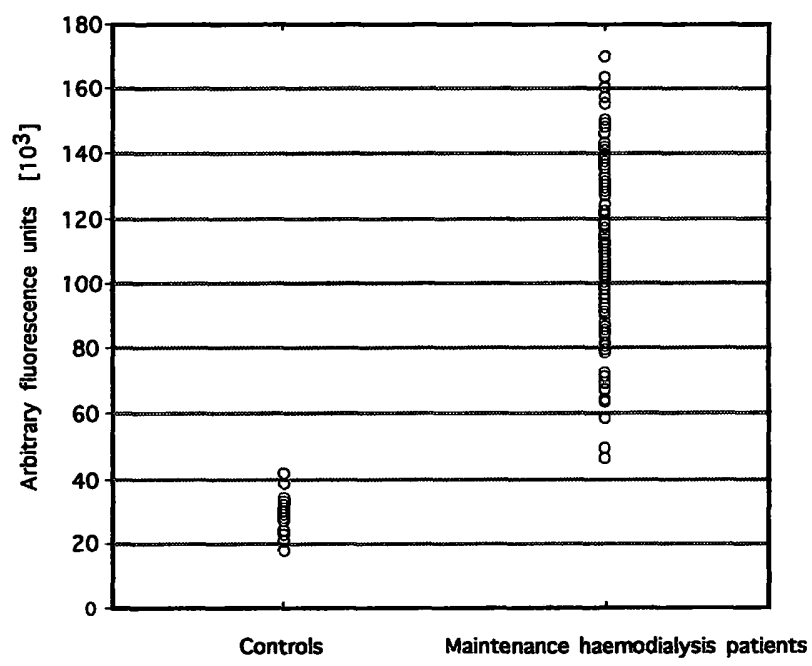

Fig. 5 Comparison of advanced glycation endproduct level in serum of haemodialysis patients and controls measured by fluorescence spectroscopy. Fluorescence spectra (emission: $370 \mathrm{~nm}$; excitation: $445 \mathrm{~nm})$ show a significant increase $(\mathrm{p}<0.0001)$ in advanced glycation endproducts in maintenance haemodialysis patients $\left(111.9 \times 10^{3} \pm 27.6 \times 10^{3}\right.$ arbitrary units, right column $)$ compared with the control subjects $\left(30.7 \times 10^{3} \pm 62 . \times 10^{3}\right.$ arbitrary units, left column). 
Secondly, the distribution of the molecular masses of the substances responsible for the advanced glycation endproduct specific fluorescence was determined in more detail by gel filtration and fluorescence detection. Fifty (50) $\mu \mathrm{l}$ of serum was separated on a TSKgel filtration column (separation range $M_{\mathrm{r}} 20000$ to 200000 ). Figure 6 shows a typical chromatogram of these serum of a haemodialysis patient with normal albumin levels prior to dialysis. Most of the fluorescence of the 10 haemodialysis patients tested co-eluted with the human serum albumin peak (retention time: $28 \mathrm{~min}$ ), with a minor peak/shoulder around $M_{\mathrm{r}} 14000$ (retention time: $41 \mathrm{~min}$ ). However, the pattern of advanced glycation endproducts distribution, particularly in the low molecular mass range, was quite different for each individual patient, probably depending on dietary uptake, residual kidney function, medication (e.g. antioxidants) and the type of haemodialysis membrane used; this will be reported elsewhere.

\section{Comparison between ELISA and fluorescence}

Comparison of the three assays showed significant differences between the control and the haemodialysis patient group independent of the assay used; the largest difference between the patient and control group was seen in the total fluorescence (fig. 7). Significant correlations of the total fluorescence with both the keyhole limpet haemocyanin advanced glycation endproduct antibody $(\mathrm{r}=0.474, \mathrm{p}<0.001, \mathrm{n}=173)$ and the imidazolone antibody $(\mathrm{r}=0.396, \mathrm{p}<0.001, \mathrm{n}=69)$ were found (fig. 8, 9). However, no correlation could be detected between the two ELISAs ( $\mathrm{r}=0.164, \mathrm{p}=0.18$, $\mathrm{n}=67$ ). This difference between the two immunological assays suggests a different distribution of advanced glycation endproducts in each patient.

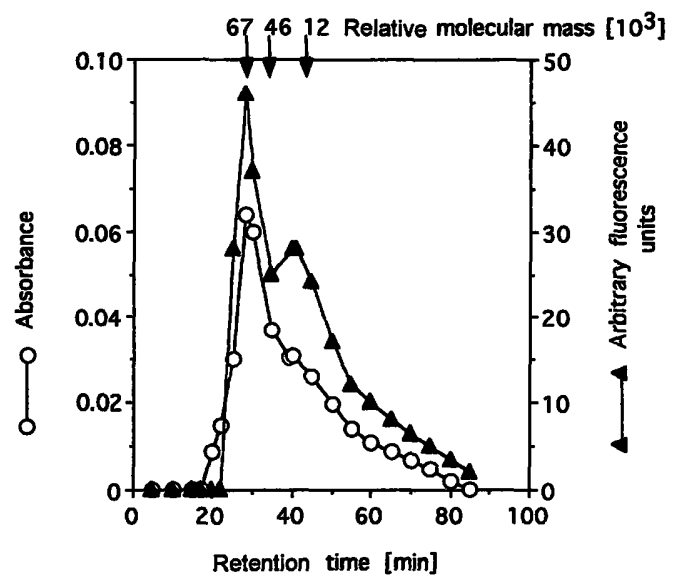

Fig. 6 Analysis of serum proteins of haemodialysis patients by gel filtration chromatography. The molecular mass distribution of the substances with advanced glycation endproduct-specific fluorescence was determined by gel filtration on a Tosohaas TSKgel G $3000 \mathrm{SW}$ gel filtration column and UV/Vis and fluorescence detection (absorption: $280 \mathrm{~nm}$, open circles; fluorescence: excitation: $370 \mathrm{~nm} /$ emission $440 \mathrm{~nm}$, triangles).

\section{Discussion}

Using competitive ELISAs with antibodies raised against various model advanced glycation endproducts, several groups have shown that plasma concentrations of advanced glycation endproducts are slightly elevated in diabetic patients with normal renal function and extremely elevated in both diabetic and non-diabetic patients with end-stage renal disease $(7-9,16)$. The most noxious fraction is believed to consist of low molecular mass advanced glycation endproducts which retain strong cross-linking activity with matrix proteins in vitro. Advanced glycation endproduct-peptides in the human circulation may represent a hitherto unrecognised class of reactive and potentially toxic substances which can exacerbate renal and extrarenal vascular pathology and render these patients sensitive to accelerated atherosclerosis. Elimination of these circulating low molecular mass advanced glycation endproducts by the kidney is impaired in patients with end-stage renal disease and this function is inadequately performed by the current types of dialysis membranes $(6,25)$. Hence a rapid and sensitive assay for the determination of advanced glycation endproducts in serum might be valuable for assessing cardiovascular risks and for monitoring the efficacy of advanced glycation endproduct removal procedures (by dialysis or adsorption), or for testing novel pharmacological approaches for inhibition of their formation.

Significantly elevated advanced glycation endproducts levels in the sera of haemodialysis patients compared with the controls were detected with each of the three advanced glycation endproduct assays. However, there was no difference between diabetic and non-diabetic patients, suggesting that increased advanced glycation endproduct formation from precursors or the insufficient

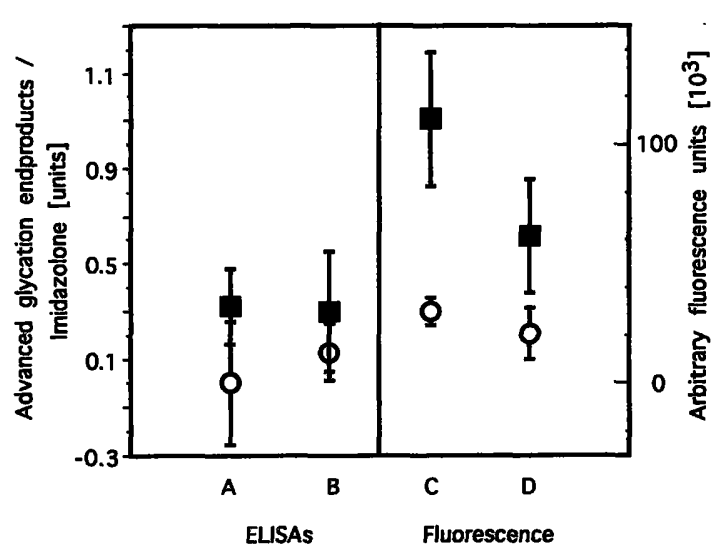

Fig. 7 Comparison between advanced glycation endproduct determinations by ELISAs and fluorescence spectroscopy. Comparison of the three assays showed significant differences between the control and the haemodialysis patient group by advanced glycation endproduct-ELISA (A), Imidazolone-.ELISA (B), total fluorescence $(C)$ and fluorescence of the protein pellet after trichloroacetic acid precipitation (D). 


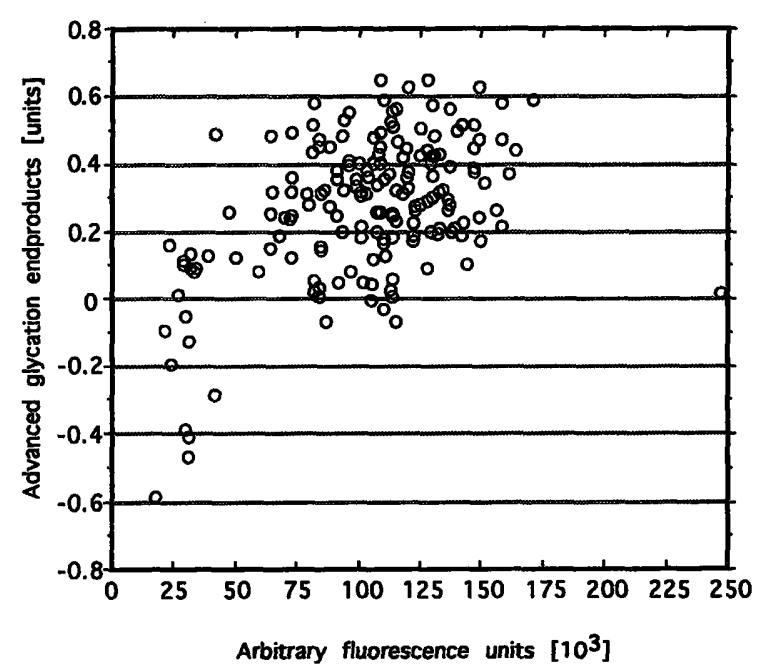

Fig. 8 Correlation of advanced glycation endproduct-ELISA with total serum fluorescence. Comparison of both assays showed a significant correlation of advanced glycation endproduct level (determined by competitive ELISA with the polyclonal keyhole limpet haemocyanin-advanced glycation endproduct antibody) and total serum fluorescence (correlation coefficient $r=0.474 ; p<0.001$ ).

clearance of advanced glycation endproducts during dialysis is more important than glycation.

Advanced glycation endproduct measurement by ELISA is quite specific, since the antibodies are specifically raised against advanced glycation endproduct-proteins or synthetic model advanced glycation endproducts. However, among the probably hundreds of different protein-bound types of advanced glycation endproducts, only a few have been chemically defined, thereby enabling their use as antigens for the production of specific antibodies; these include carboxymethyllysine, imidazolone, pentosidine and pyrraline (26-28). Antibodies used in ELISAs for advanced glycation endproduct can range from very specific monoclonal antibodies against synthetic compounds such as imidazolone to general polyclonal antibodies against an advanced glycation endproduct modified protein such as keyhole limpet haemocyanin. Further disadvantages of the immunological assays are the low sensitivity (detection limit: $75 \mu \mathrm{l}$ serum for a triplicate determination) as well as the long analysis time which limits their use for advanced glycation endproduct measurement during dialysis (tab. 3).

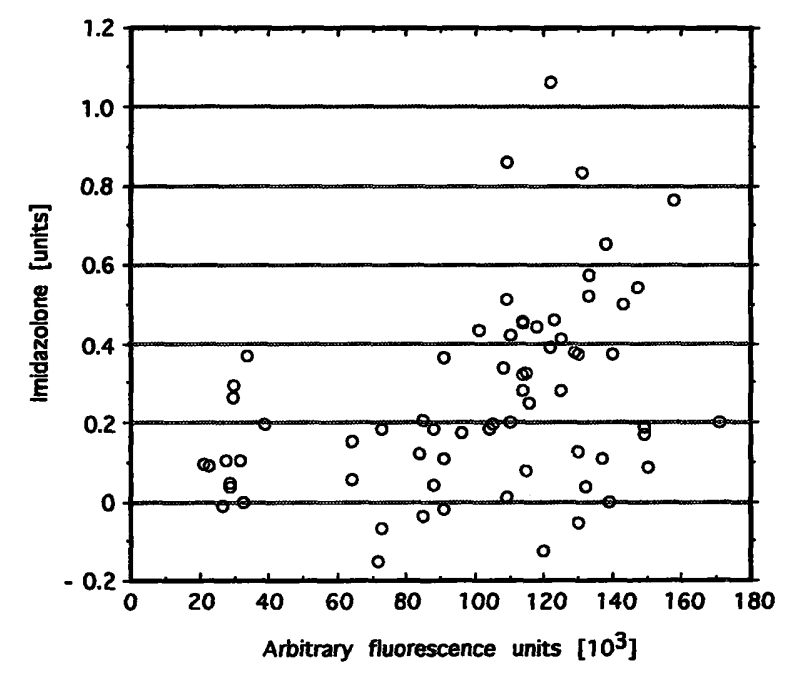

Fig. 9 Correlation of imidazolone-ELISA with total serum fluorescence. Comparison of both assays showed a significant correlation of imidazolone level (determined by competitive ELISA with the monoclonal imidazolone antibody) and total serum fluorescence (correlation coefficient $r=0.396 ; p<0.001$ ).

As long as the pathophysiological relevance of a certain advanced glycation endproduct's structure is not known, it is difficult to select one particular advanced glycation endproduct as the antigen for an immunological assay.

Total fluorescence of serum measures a combination of mainly protein-bound glycoxidation and oxidation products. Among the many fluorescent advanced glycation endproducts, only a few have been identified so far. Pentosidine is a fluorescent condensation product of lysine, arginine and ribose. However, its emission maximum at $395 \mathrm{~nm}$ (excitation: $335 \mathrm{~nm}$ ) is not characteristic for native advanced glycation endproducts, suggesting that this is only a minor product (29). A second class of fluorescent compounds, the crosslinks, were shown to be one of the major fluorescent advanced glycation endproducts produced in a reaction mixture of free amino groups such as lysine with glucose in vitro, with fluorescent spectra similar to those of advanced glycation endproduct proteins (30). Our data show that total fluorescence is mainly associated with high molecular mass proteins, particularly albumin. This is supported by Monnier et al., who showed that $90 \%$ of pentosidine of

Tab. 3 Comparison of advanced glycation endproduct assays in terms of sample size, time requirements and inter-assay variations

\begin{tabular}{llll}
\hline & $\begin{array}{l}\text { ELISA } \\
\text { (advanced glycation endproduct) }\end{array}$ & $\begin{array}{l}\text { ELISA } \\
\text { (imidazolone) }\end{array}$ & Fluorescence spectroscopy \\
\hline Sample size (triplicate) & $75 \mu \mathrm{l}$ & $75 \mu \mathrm{l}$ & $20 \mu \mathrm{l}$ \\
Analysis time & $>4 \mathrm{~h}$ & $>4 \mathrm{~h}$ & $<10 \mathrm{~min}$ \\
Inter-assay variation & $6.60 \%$ & $5.54 \%$ & $8.9 \%$ \\
& (triplicates on the same day) & (triplicates on the same day) & $\begin{array}{l}\text { (triplicates on the same day) } \\
\end{array}$ \\
& $\begin{array}{l}8.75 \% \\
\text { (day to day variation, 3 days) }\end{array}$ & $\begin{array}{l}4.35 \% \\
\text { (day to day variation, 3 days) }\end{array}$ & $\begin{array}{l}10.5 \% \\
\text { (day to day variation, 5 days) }\end{array}$ \\
\hline
\end{tabular}


plasma proteins from end-stage renal disease patients is linked to high molecular mass proteins and only $1-2 \%$ is in free form (31).

The correlation of total fluorescence with advanced glycation endproduct level measured by ELISA indicates that the chemical reactions leading to the generation of fluorescence and both antigenic epitopes are related, probably involving an oxidation step of the glycated protein. The non-significant correlation between the two ELISAs, however, shows that both antigenic structures are unequally distributed in the maintenance haemodialysis patients. This difference between the two immunological assays suggests a distinct distribution of advanced glycation endproducts for each patient.

The relevance and specificity of total fluorescence is still controversial. As demonstrated by us and other authors, low molecular mass fluorescent advanced glycation endproducts, e.g. derived from nutrition, are only a minor problem since the main fluorescent species are protein-bound compounds (31). Although the fluorescent compounds contained in lipofuscin, ceroid, advanced glycation endproducts, and age pigment-like fluorophores can be produced from different types of biological materials by side reactions during essential biological processes, the crosslinking of carbonylamino compounds is recognised as a common process during their formation (32).

\section{References}

1. Brownlee M. Advanced protein glycosylation in diabetes and aging. Annu Rev Med 1995; 46:223-34.

2. Monnier VM, Cerami A. Nonenzymatic browning in vivo: possible process for aging of long-lived proteins. Science 1981; 211:491-3.

3. Niwa T, Katsuzaki T, Miyazaki S, Momoi T, Akiba T, Miyazaki $\mathrm{T}$, et al. Amyloid beta(2)-microglobulin is modified with imidazolone, a novel advanced glycation end product, in dialysisrelated amyloidosis. Kidney Int 1997; 51:187-94.

4. Monnier VM, Nagaraj RH, Porterootin M, Glomb M, Elgawish $\mathrm{AH}$, Sell DR, et al. Structure of advanced Maillard reaction products and their pathological role. Nephrol Dial Transplant 1996; 11 Suppl 5:20-6.

5. Odetti P, Pronzato MA, Noberasco G, Cosso L, Traverso N, Cottalasso D, et al. Relationships between glycation and oxidation related fluorescences in rat collagen during aging - an in vivo and in vitro study. Lab Invest 1994; 70:61-7.

6. Vlassara H, Bucala R, Striker L. Biology of disease. Pathogenic effects of advanced glycosylation: biochemical, biologic, and clinical implications for diabetes and aging. Lab Invest 1994; 70:138-51.

7. Friedlander MA, Wu YC, Schulak JA, Monnier VM, Hricik DE. Influence of dialysis modality on plasma and tissue concentrations of pentosidine in patients with end-stage renal disease. Am J Kidney Dis 1995; 25:445-51.

8. Gerbitz KD, Dolhofer-Bliesener R, Lechner B, Deppisch R, Ritz E. Immunological determination of advanced glycation endproducts in human blood and urine. Nephrol Dial Transplant 1995; 10:657-4.

9. Gerbitz KD, Dolhofer-Bliesener R, Lechner B. Possible significance of advanced glycation end products in serum in endstage renal disease and in complications of diabetes. Eur J Clin Chem Clin Biochem 1996, 34:355-61.
Formation of advanced glycation endproducts and protein oxidation are closely linked. In particular, glycated proteins produce superoxide radicals which lead to a site-specific oxidation of adjacent proteins (33). In addition, not only protein-bound Amadori-products, but also on amino acids are subject to transition metal-catalysed oxidation, leading to the formation of advanced oxidation protein products. Their levels have been shown to correlate with plasma concentrations of dityrosine and advanced glycation endproduct-pentosidine, as indices of oxidant-mediated protein damage, but not with thiobarbituric acid reactive substances which serve as lipid peroxidation markers. In a further study, the level of pentosidine, a marker of glycation, and the intensity of collagen-linked fluorescence glycation (370/440 and 335/385 nm), and oxidation-related ( $356 / 460$ and $390 / 460 \mathrm{~nm})$ and glycated haemoglobin showed a good correlation (34).

However, for the rapid monitoring of the removal of low molecular mass serum advanced glycation endproducts from dialysis patients, the precise origin of the fluorescent substances might be of secondary importance. They might rather serve as representative markers for the efficacy of dialysis.

\section{Acknowledgements}

We thank U. Schindler, M. Bühner, K. Sebetkova and J. Michaelis for valuable discussions.

10. Münch G, Double K, Schinzel R, Riederer P. Advanced glycation endproducts and oxidative stress - a vicious circle in neurodegeneration? Alzheimer's Dis Rev 1996; 1:71-4.

11. Bucala R, Cerami A. Advanced glycosylation: chemistry, biology, and implications for diabetes and aging. Adv Pharmacol 1992; 23:1-34.

12. Smith MA, Sayre LM, Monnier VM, Perry G. Radical AGEing in Alzheimer's disease. Trends Neurosci 1995; 18:172-6.

13. Palinski W, Koschinsky T, Butler SW, Miller E, Vlassara H, Cerami A, et al. Immunological evidence for the presence of advanced glycosylation end products in atherosclerotic lesions of euglycemic rabbits. Arterioscler Thromb Vasc Biol 1995; 15:571-82.

14. Schmidt AM, Hori O, Chen JX, Li JF, Crandall J, Zhang $\mathrm{J}$, et al. Advanced glycation endproducts interacting with their endothelial receptor induce expression of vascular cell adhesion molecule-1 (VCAM-1) in cultured human endothelial cells and in mice. A potential mechanism for the accelerated vasculopathy of diabetes. J Clin Invest 1995; 96:1395-403.

15. Vlassara H, Striker LJ, Teichberg S, Fuh H, Li YM, Steffes M. Advanced glycation end products induce glomerular sclerosis and albuminuria in normal rats. Proc Natl Acad Sci USA 1994; 91 Suppl 24:11704-8.

16. Papanastasiou P, Grass L, Rodela H, Patrikarea A, Oreopoulos D, Diamandis EP. Immunological quantification of advanced glycosylation end-products in the serum of patients on hemodialysis or CAPD. Kidney Int 1994; 46:216-22.

17. Deutscher MP, editor. Guide to protein purification. San Diego: Academic Press, 1990.

18. Fairbanks VF, Klee GG. Biochemical aspects of hematology. In: Burtis CA, Ashwood ER, editors. Tietz textbook of clinical chemistry. Philadelphia: Saunders, 1994:1974-2072. 
19. Reddy S, Bichler J, Wells-Knecht KJ, Thorpe SR, Baynes JW. $\mathrm{N}$ epsilon-(carboxymethyl)lysine is a dominant advanced glycation end product (AGE) antigen in tissue proteins. Biochemistry $1995 ; 34: 10872-8$.

20. Ideda K, Higashi T, Sano H, Jinnouchi Y, Yoshida M, Araki $\mathrm{T}$, et al. $\mathrm{N}$-epsilon-(carboxymethyl)lysine protein adduct is a major immunological epitope in proteins modified with advanced glycation end products of the Maillard reaction. Biochemistry $1996 ; 35: 8075-83$.

21. Chio KS, Tappel AL. Synthesis and characterization of the fluorescent products derived from malonaldehyde and amino acids. Biochemistry 1969; 8:2821-6.

22. Wickens DG, Norden AG, Lunec J, Dormandy TL. Fluorescence changes in human gamma-globulin induced by free-radical activity. Biochim Biophys Acta 1983; 742:607-16.

23. Miyata T, Maeda K, Kurokawa K, Destrihou CV. Oxidation conspires with glycation to generate noxious advanced glycation end products in renal failure. Nephrology, Dialysis, Transplantation $1997 ; 12: 255-8$.

24. Nguyenkhoa T, Nguyen NT, Zingraff J, Jungers P, Descampslatscha B. Advanced oxidation protein products as a novel marker of oxidative stress in uremia. Kidney Int 1996; 49:1304-13.

25. Makita Z, Bucala R, Rayfield EJ, Friedman EA, Kaufman AM, Korbet SM. Reactive glycosylation endproducts in diabetic uraemia and treatment of renal failure. Lancet 1994; 343:1519-22.

26. Smith MA, Taneda S, Richey PL, Miyata S, Yan SD, Stern D, et al. Advanced Maillard reaction end products are associated with Alzheimer disease pathology. Proc Natl Acad Sci USA 1994; 91:5710-4.

27. Monnier VM, Sell DR, Miyata S, Nagaraj RH,Odetti P, Lapolla A. Advanced Maillard reaction products as markers for tissue damage in diabetes and uraemia - relevance to diabetic nephropathy Acta Diabetol 1992; 29:130-135.
28. Niwa T, Sato M, Katsuzaki T, Tomoo T, Miyazaki T, Tatemichi $\mathrm{N}$, et al. Amyloid beta(2)-microglobulin is modified with $\mathrm{N}$ epsilon-(carboxymethyl)lysine in dialysis-related amyloidosis. Kidney Int 1996; 50:1303-9.

29. Bellmunt MJ, Portero M, Pamplona R, Muntaner M, Prat J. Age-related fluorescence in rat lung collagen Lung 1995; 173:177-85.

30. Obayashi H, Nakano K, Shigeta H, Xamaguchi M, Yoshimori $\mathrm{K}$, Fukui $\mathrm{M}$, et al. Formation of crosslinks as a fluorescent advanced glycation end product in vitro and in vivo. Biochem Biophys Res Commun 1996; 226:37-41.

31. Friedlander MA, Wu YC, Elgawish A, Monier VM. Early and advanced glycosylation end products - kinetics of formation and clearance in peritoneal dialysis. J Clin Invest 1996; 97:728-35.

32. Yin DZ. Biochemical basis of lipofuscin, ceroid, and age pigment-like fluorophores. Free Rad Biol Med 1996; 21:871-88.

33. Mullarkey CJ, Edelstein D, Brownlee M. Free radical generation by early glycation products: a mechanism for accelerated atherogenesis in diabetes. Biochem Biophys Res Commun $1990 ; 173: 932-9$.

34. Odetti P, Traverso N, Cosso L, Noberasco G, Pronzato MA, Marinari UM: Good glycaemic control reduces oxidation and glycation end-products in collagen of diabetic rats. Diabetologia 1996; 39:1440-7.

Received January 31/June 9, 1997

Corresponding author: Dr. Reinhard Schinzel, Physiologische Chemie I, Biozentrum, Am Hubland, D-97074 Würzburg, Germany

Fax: +499318884150, e-mail: schinzel@biozentrum.uniwuerzburg.de 
